\title{
Falls in the general elderly population: a 3 - and 6- year prospective study of risk factors using data from the longitudinal population study 'Good ageing in Skane'
}

\author{
Magnus Stenhagen ${ }^{*}$, Henrik Ekström, Eva Nordell and Sölve Elmståhl
}

\begin{abstract}
Background: Accidental falls in the elderly are a major health problem, despite extensive research on risk factors and prevention. Only a limited number of multifactorial, long-term prospective studies have been performed on risk factors for falls in the general elderly population. The aim of this study was to identify risk factors predicting falls in a general elderly population after three and six years, using a prospective design.

Methods: The prevalence of 38 risk factors was recorded at a baseline assessment of 1763 subjects (aged 60-93 years). The incidence of one or more falls was recorded after three and six years. The predicted risk of falling, after exposure to the various risk factors, was analysed in a multiple logistic regression model, adjusted for age and sex, and presented as odds ratios (OR). A principal component analysis (PCA), including the statistical significant factors, was also performed to identify thematic, uncorrelated components associated with falls.

Results: The use of neuroleptics (OR 3.30, 95\% Cl: 1.15-9.43), heart failure with symptoms (OR 1.88, 95\% Cl: 1.173.04) and low walking speed (OR 1.77, 95\% Cl: 1.28-2.46) were prominent individual risk factors for falls. In the PCA, three main components predicting falls were identified: reduced mobility, OR 2.12 (95\% Cl 1.54-2.91), heart dysfunction, OR 1.66 (95\% Cl 1.26-2.20) and functional impairment including nocturia, OR 1.38 (95\% Cl 1.01-1.88).

Conclusions: Three main components predicting falls were identified in a general elderly population after three and six years: reduced mobility, heart dysfunction and functional impairment including nocturia. The use of neuroleptic drugs was also a prominent individual risk factor, although the prevalence was low. Heart failure with symptoms was a significant risk factor for falls and may be of clinical importance as the prevalence of this condition in the elderly is increasing worldwide. There is need for further research on the relation between heart failure and falls in the elderly, as the treatment for this condition is poorly documented in this demographic. The findings of this study may be valuable in the development of intervention programmes aimed at sustainable, long-term reduction of falls in the elderly.
\end{abstract}

Keywords: Accidental falls, Elderly, Epidemiology, Prospective, General population, Risk factors, Predictors

\footnotetext{
* Correspondence: magnus.stenhagen@med.lu.se

Department of Health Sciences, Division of Geriatric Medicine, Lund

University, Skåne University Hospital, Malmö SE-205 02, Sweden
} 


\section{Background}

Although accidental falls in the elderly have been the subject of extensive research during the past 20 years, it is still a major health problem in a rapidly ageing global population [1-6]. Unintentional injuries are the fifth leading cause of death in older adults after cardiovascular, neoplastic, cerebrovascular and pulmonary causes. Falls are responsible for two-thirds of the fatalities resulting from unintentional injuries [2,7]. About a third of community-dwelling people over 65 years fall each year, and the incidence increases with age [1]. Approximately $20 \%$ of accidental falls require medical attention, and 5\% results in a fracture or other serious injuries [8]. The additional psychological and social consequences can be severe, with post-fall syndromes including fear, depression and activity avoidance $[2,7,9,10]$. The high incidence of falls in the elderly, with substantial mortality and morbidity, underlines the importance of preventive interventions. Many preventive programmes and randomised controlled trials based on reported risk factors have been conducted and evaluated over the years $[1,11,12]$. Although some interventions have proven to be effective in reducing falls, there is still some uncertainty about the optimal approach and the efficacy of interventions aimed at preventing falls, probably due to the complex nature and aetiology of the clinical problem [2,7,8,12-15].

Risk factors for falls have been identified in epidemiological studies of varying quality [1]. Meta-studies show a notable heterogeneity in the selection, scope and methodology employed in previous studies, in which falls were assessed retrospectively, or small, unrepresentative samples of the general elderly population were studied with short follow-up periods [3,5,16,17]. As retrospective and cross-sectional studies can identify risk factors, they are methodologically weaker than prospective studies, which have the ability to assess outcome after exposure to risks [18]. Three systematic reviews of studies on risk factors for falls in subjects over 64 years of age include 23 prospective studies, from 1988 to 2009 $[3,16,17]$. The follow-up period ranged from 16 days to a maximum of 16 months, and most had an one-year duration. An additional, recent systematic meta-analysis included 74 prospective studies from 1988 to 2009, in which risk factors for falls in community-dwelling older people were analysed [19]. The majority of these studies had a duration of one year or less, and sample sizes less than 500 subjects. Five studies had a duration of over 36 months (range 48-84 months), although they focused on one or few risk factors, and had skewed gender distributions.

As the cause of falls in the elderly is largely multifactorial, it is relevant to analyse a broad range of intrinsic and extrinsic risk factors for falls $[7,20]$. Saari $(2007)$ and
Pluijm (2006) applied a multifactorial approach with 10 - and 3-year follow-ups, respectively [21,22]. Anstey (2006) employed an 8-year prospective design in studying the relation between cognitive performance and falls [23]. Besides these, to our knowledge, few long-term, multifactorial prospective cohort studies on risk factors for falls in the general elderly population have been carried out. Such long-term prospective studies are vital if we are to understand the processes behind falling, to be able to predict and define groups at risk, and to improve the design of future clinical trials [18]. As the first step in an effective intervention programme may be identifying risk factors for falls, their identification in a longterm perspective may be vital in future interventions aimed at a stable, long-term reduction of falls.

This study is based on a large cohort from the general elderly population, including the very elderly, with longterm follow-up assessments. The aim of this study was to identify risk factors predicting falls in a general elderly population after three and six years. The results are also presented in terms of thematic components, using a multifactorial approach in which a wide range of risk factors for falls was analysed.

\section{Methods}

\section{Study population}

This a prospective cohort study based on data from the on-going longitudinal, Swedish population study 'Good Ageing in Skåne' [24]. Initially, 5370 subjects from five municipalities, covering both urban and rural areas, in the region of Skåne, southern Sweden, were invited to participate by letter. The subjects were randomly selected from the National Population Register using a computerised random number generator. The only exclusion criterion was the inability to speak Swedish. The study included men and women from nine age cohorts: 60, 66, 72, 78, 81, 84, 87, 90 and 93 years. Nearly 3000 individuals (2931) agreed to participate, giving a response rate of $60 \%$. These subjects were recruited to a baseline assessment which took place from February 2001 to July 2004; a lengthy inclusion period was needed due to the scope of the study. The assessments were performed at a research centre or at the subject's own home $(9.7 \%)$, or in sheltered housing $(2.5 \%)$. The older cohorts, 78 years and older, were invited to a 3-year follow-up assessment between January 2005 and June 2006. All cohorts were invited to a 6-year follow-up between March 2007 and December 2011. Figure 1 illustrates the study population, which initially consisted of 2535 subjects in which no falls were recorded at the baseline assessment. After recruitment, 772 subjects did not participate in the follow-up assessments, and were thus categorised as non-participants. In total, 1763 


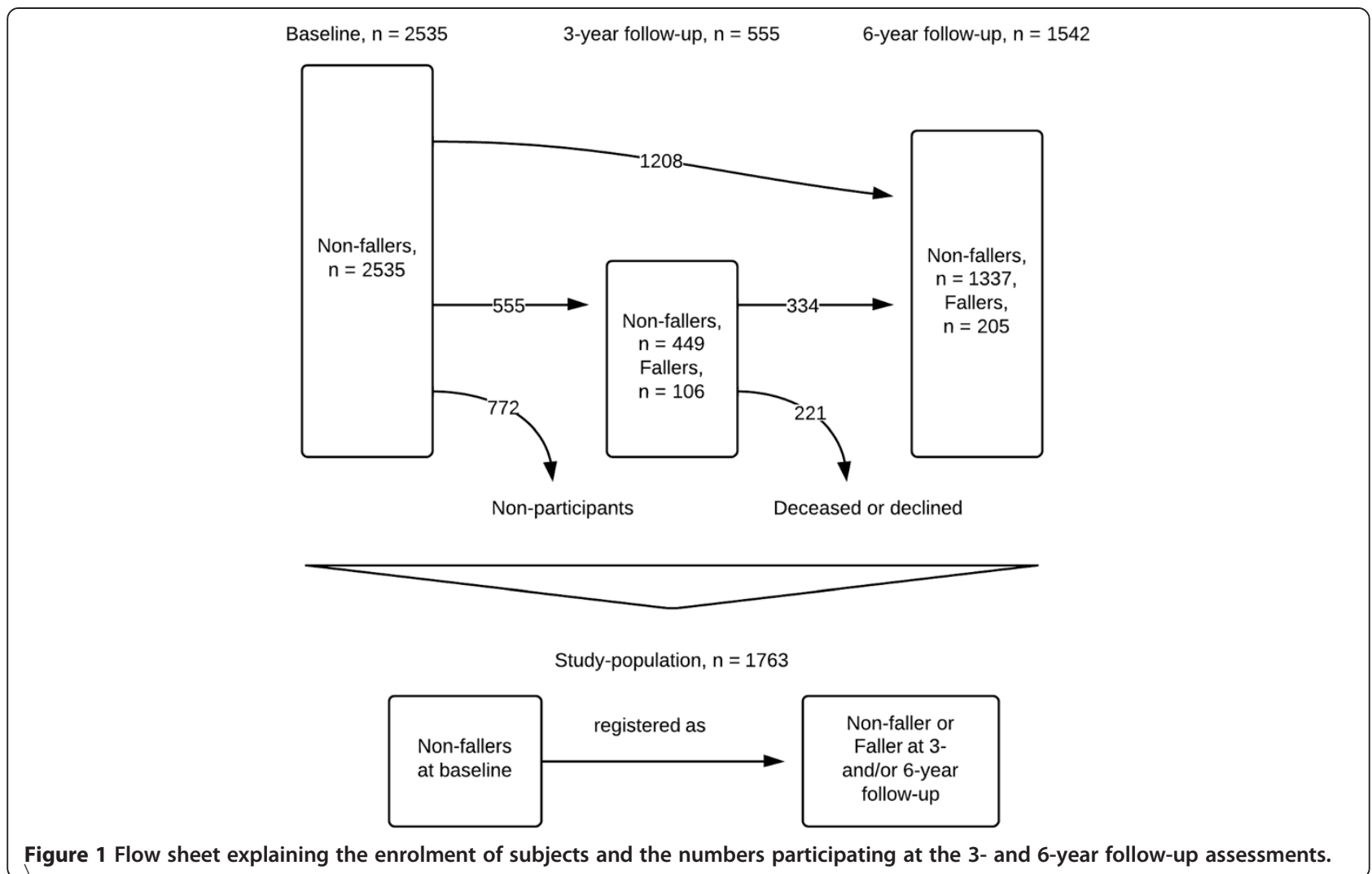

subjects with complete data from the 3- or/and 6-year follow-up assessments were included in our study.

\section{Data collection and definition of variables}

At baseline and the follow-up assessments, the subjects underwent a comprehensive health examination by a physician and other trained medical staff. A physical examination and cognitive assessment were carried out, their medical history was obtained, and diagnoses and medication were recorded. Self-reported questionnaires were used to obtain data on functional, physical, psychological and life-style factors.

Systematic reviews and meta-analyses have identified a number of well-established risk factors for falls: advanced age, female gender, gait and balance deficits, muscle weakness, low walking speed, dizziness and vertigo, mobility limitations and the use of assistive devices, living alone, pain, functional limitations with dependence in activities of daily living (ADL), assisted toileting, cognitive impairment and confusion $[2,7,11,16,19]$. Medical conditions such as cardiovascular disease and heart failure, diabetes, arthritis, dementia, depression and incontinence are also established risk factors $[11,16,19]$. Additionally, the use of medication, a highly adjustable risk factor, is associated with falls in the elderly, especially psychoactive, neuroleptic and anticholinergic drugs $[11,16,19,25-28]$. The included factors have been divided into established categories: medical and psychological factors, medication use, sensory and neuromuscular factors, balance and mobility factors, and environmental and sociodemographic factors [29]. In an attempt to cover these areas, 38 intrinsic and extrinsic factors were included and recorded as exposure variables at the baseline assessment. These variables have been defined in a previous cross-sectional study of the baseline population [30].

\section{Falls}

Purpose-trained physicians collected data on falls, the dependent variable, at face-to-face interviews with the subjects at the 3- and 6-year assessments. Using a structured questionnaire, the subject was asked: "Have you fallen once or more in the last six months?" No standardised definition of a fall was used [31,32]. Those who reported one or more falls in the preceding six months were dichotomised as 'fallers'. The occurrence, frequency or severity (e.g. requiring medical attention) of the event was not included in this dichotomised approach.

\section{Medical and psychological factors}

The categorisation of somatic diseases was based on the International Classification of Diseases (ICD-10) criteria after examination by a physician. The factor heart disease included angina, myocardial infarction and 
arrhythmia. Heart failure with symptoms was identified using the New York Heart Association (NYHA) criteria, and included subjects with NYHA class II-IV symptoms [33]. The factor stroke included cerebral infarction, haemorrhage and transient ischaemic attack. Anaemia was classified using a venous blood sample $(\mathrm{Hb}<134 \mathrm{~g} /$ $\mathrm{L}$ for men, $\mathrm{Hb}<117 \mathrm{~g} / \mathrm{L}$ for women) [34]. The criteria in the Diagnostic and Statistical Manual of Mental Disorders (DSM-IV) were used for the psychiatric diagnoses depression and psychosis, in an examination by a physician. A score below 24 points on the Mini-Mental State Examination scale defined cognitive impairment [35]. The prevalence of sleeping disorders was assessed using a self-reported questionnaire.

\section{Medication use}

The subject's on-going medication was recorded at baseline by a physician, and categorised according to the Anatomical Therapeutic Chemical classification system [36]. The use of sedatives/hypnotics, neuroleptics, anticholinergic drugs, antihypertensive drugs (beta-blockers, ACE inhibitors, calcium-channel blockers) and diuretics (thiazide and loop diuretics) was included as risk factors, based on the results of previous meta-studies [27,37-39]. Additionally, the use of one or more of these medications was categorised as the factor 'use of fall risk drugs', while the use of other drugs apart from these was categorised as 'use of other drugs'.

\section{Sensory and neuromuscular factors}

Vertigo, current pain, urine incontinence and nocturia were assessed using self-reported questionnaires.

\section{Balance and mobility factors}

Information on a self-perceived tendency to fall and pain during movement was obtained from a self-reported questionnaire. Impaired mobility was defined as using a walking aid. Walking speed was measured by timing the subject's maximal walking speed over 15 metres without running. Low walking speed was defined as a time above the median value of the study population. A score of one or two on the six-level Mattiasson-Nilo scale was classified as low physical activity [40].

\section{Environmental and sociodemographic factors}

Information about the subject's housing situation was obtained from a questionnaire. Residential home was defined as living in sheltered housing, or in a retirement or nursing home. Outdoor adaptation of housing was defined as the provision of improved accessibility for people with mild or severe disabilities, or those in wheelchairs. Indoor adaptation was defined as having thresholds removed, the bath replaced by a shower, all rooms being made accessible by wheelchair, and/or the installation of a contact alarm or a stair-lift. Age and gender were recorded at recruitment to the study.

Functional ability was assessed by self-reporting on Hulter-Åsberg's ADL scale [41,42]. Nine activities were divided into instrumental activity of daily living (iADL, e.g. transportation, shopping) and personal activity of daily living (pADL, e.g. eating, dressing). Dependence in iADL was defined as independency of activities of pADL with dependency in at least one activity of iADL. Dependence in $\mathrm{pADL}$ was defined as dependency in a least one activity of pADL. Hulter-Åsberg's ADL scale has been evaluated for both reliability and validity $[41,42]$.

\section{Statistical analysis}

All variables were coded into dichotomised values except age, which was categorised according to the included cohorts: $60,66,72,78,81,84,87,90$ and 93 years. The association between exposure to the individual risk factor at baseline and the incidence of falls after three or six years was statistically analysed using crude odds ratios (OR). Multiple logistic regression analysis, adjusted for age and sex, was used to calculate the predicted risk of falling, and was presented as the OR to fall when exposed to the particular risk factor.

As a large set of variables was analysed in this study, principal component analysis (PCA) was used to group significant factors into smaller thematic and manageable components. This approach was used to reduce collinearity and to produce a smaller number of linear, uncorrelated components associated with falls, with all of the variance in the variables being used. The significant factors identified by multiple regression analysis adjusted for age and sex, were subjected to this analysis. Prior to performing PCA, the suitability of the data was assessed, as described in the Results section. The factors in each retained component were dichotomised into a 'dummy-variable', representing the whole component. The ORs for falling for these components were analysed in a final multiple logistic regression model, with the components adjusted for each other.

An attrition analysis was carried out to examine and compare the non-participants $(\mathrm{n}=772)$ with the participants. This analysis was based on data collected on the subjects recruited at baseline who did not participated in the follow-up assessments for various reasons. The chisquared test was used to analyse statistical differences between the groups.

The SPSS software package version 18 was used for all statistical analyses. A 95\% confidence interval (CI), and a p-value $<0.05$ defined statistical significance.

\section{Ethics}

The study was approved by the Ethics Committee of Lund University, Sweden, and all subjects gave their written informed consent. 


\section{Results}

The study population included $45.7 \%$ men and $54.3 \%$ women. Just over half the study population was in their sixties at baseline (55.5\%). Approximately one in five was in their seventies or eighties (19.9\% / 21.5\%), and only $3.1 \%$ was in their nineties. Table 1 presents data on the incidence of falls and the basic characteristics of those defined as fallers. At the 3-year follow-up assessment, including the older subjects (78 years and older at baseline), the incidence of falls in the past six months was almost one in five (19.1\%). At the 6-year follow-up assessment, almost one in seven of the participants had fallen once or more in the past six months (13.3\%). Falls were almost four times more common in 90-year-olds than in 60-years olds at the 6-year assessment, and women fell almost twice as often as men throughout the study. The prevalence of risk factors at baseline, and their association with falls are presented in Table 2 . Eleven factors were statistically significant in the ageand sex-adjusted regression model (indicated by boldface in the far right-hand column of Table 2), with ORs for falling ranging from 1.35 to 3.30 . The use of neuroleptics (OR 3.30, 95\% CI 1.15-9.43), heart failure with symptoms (OR 1.88, 95\% CI 1.17-3.04), and low walking speed (OR 1.77, 95\% CI 1.28-2.46) were the most prominent risk factors.

The eleven statistically significant factors were included in the PCA. Examination of the correlation matrix obtained from the PCA revealed the presence of nine coefficients of 0.3 and above, the value indicating a moderate positive relationship according to our definition. The analysis revealed four independent components with eigenvalues exceeding 1, explaining $51.7 \%$ of the variance. Inspection of the screen plot revealed a clear break after the third component. As the fourth component consisted of a single variable, a threecomponent solution was chosen (Table 3). Direct oblimin rotation was used to calculate the factor

Table 1 Basic characteristics of fallers at the 3- and 6-year follow-up assessments, $n=1763$

\begin{tabular}{llllll}
\hline & \multicolumn{2}{l}{ 3-year follow-up } & & \multicolumn{2}{c}{ 6-year follow-up } \\
\cline { 2 - 3 } & n, faller/total & $\%$ & & $\mathbf{n}$, faller/total & $\%$ \\
\hline All & $106 / 555$ & 19.1 & & $205 / 1542$ & 13.3 \\
Age in decades & & & & $106 / 979$ & 10.8 \\
60 & - & - & 13.2 & $40 / 303$ & 13.2 \\
70 & $21 / 159$ & 20.0 & $47 / 230$ & 20.4 \\
80 & $68 / 343$ & 32.1 & $12 / 30$ & 40.0 \\
90 & $17 / 53$ & & & \\
\hline Sex & & 14.8 & $68 / 716$ & 9.5 \\
Men & $34 / 230$ & 22.2 & $137 / 826$ & 16.6 \\
Women & $72 / 325$ & & &
\end{tabular}

loadings of the variables and no correlation between the components over 0.3 was found. The first component, called reduced mobility, included the factors indoor adaptation, osteoarthritis of hip and/or knee, low walking speed and impaired mobility. It explained $21.3 \%$ of the variance and had an OR for falling of 2.12 (95\% CI 1.54-2.91). The second component, consisting of heart disease, heart failure with symptoms and the use of fall risk drugs, was called heart dysfunction, and explained $11.2 \%$ of the variance with an OR for falling of 1.66 (95\% CI 1.26-2.20). The final component, called functional impairment, included dependence in pADL and nocturia, and explained $9.8 \%$ of the variance, with an OR for falling of 1.38 (95\% CI 1.01-1.88).

The attrition analysis revealed that there were significantly relatively more 80 - and 90 -year-olds in the group of non-participants than in the included study population (Table 4). Risk factors such as heart disease, tendency to fall, the use of fall risk drugs and low walking speed were significantly more prevalent in the nonparticipants.

\section{Discussion}

We found that the component reduced mobility was a prominent predictor of falling. This is in accordance with previous findings, where several studies have revealed a relationship between low walking speed and falls in the elderly $[43,44]$. Knee pain and lower back pain have also been significantly associated with multiple falls, predominantly in women $[44,45]$. Osteoarthritis and pain in the musculoskeletal system may reduce the ability of the individual to maintain an upright position in non-ideal surroundings, and treatment with opioids may cause additional adverse effects in the elderly, such as dizziness. Randomised trials and systematic reviews have shown that exercise, strength and balance training can significantly reduce both non-injurious and injurious falls in the elderly $[1,8,13]$.

The association between heart dysfunction and future falls is partly a confirmatory finding, where the most common cardiovascular disorders associated with falls are carotid sinus hypersensitivity, vasovagal syndrome and brady- and tachyarrhythmias [46]. However, heart failure with symptoms was a prominent individual predictor, which may not have been widely reported. This may be clinically relevant, as heart failure is a cardiovascular disease with increasing incidence and prevalence, and in an ageing population it can be expected to rise significantly in the coming decades $[47,48]$. According to a previous review, there is a relative lack of published clinical trials in which the efficacy of heart failure treatment has been assessed exclusively in elderly individuals [47]. In a recent geriatric study, falls and urinary incontinence were reported as being common comorbidities 
Table 2 Prevalence of risk factors and their association with falls according to adjusted multiple regression analysis, expressed as odds ratios (OR), $n=1763$

\begin{tabular}{|c|c|c|c|c|c|c|}
\hline Risk factors & & $\begin{array}{l}\text { Non-fallers } \\
\mathrm{n} / \%\end{array}$ & $\begin{array}{l}\text { Fallers } \\
\mathrm{n} / \%\end{array}$ & $\begin{array}{l}\text { Crude OR } \\
(95 \% \mathrm{Cl})\end{array}$ & $\begin{array}{l}\text { OR adjusted for age } \\
(95 \% \mathrm{Cl})\end{array}$ & $\begin{array}{l}\text { OR adjusted for age and sex } \\
(95 \% \mathrm{Cl})\end{array}$ \\
\hline \multicolumn{7}{|l|}{ Medical and psychological } \\
\hline Heart disease & $\begin{array}{l}\text { No } \\
\text { Yes }\end{array}$ & $\begin{array}{l}1169 / 85 \\
299 / 77 \\
\end{array}$ & $\begin{array}{l}203 / 15 \\
88 / 23 \\
\end{array}$ & $\begin{array}{l}\mathbf{1 . 7 0} \\
(1.28-2.24)\end{array}$ & $\begin{array}{l}1.26 \\
(0.94-1.69) \\
\end{array}$ & $\begin{array}{l}\mathbf{1 . 3 6} \\
(1.00-1.83)\end{array}$ \\
\hline Heart failure with symptoms & $\begin{array}{l}\text { No } \\
\text { Yes }\end{array}$ & $\begin{array}{l}1369 / 84.5 \\
60 / 65.9 \\
\end{array}$ & $\begin{array}{l}252 / 15.5 \\
31 / 34.1 \\
\end{array}$ & $\begin{array}{l}\mathbf{2 . 8 1} \\
(1.78-4.42)\end{array}$ & $\begin{array}{l}\mathbf{1 . 7 6} \\
(1.10-2.83)\end{array}$ & $\begin{array}{l}\mathbf{1 . 8 8} \\
(1.17-3.04)\end{array}$ \\
\hline Stroke & $\begin{array}{l}\text { No } \\
\text { Yes }\end{array}$ & $\begin{array}{l}1368 / 84.3 \\
98 / 72.6 \\
\end{array}$ & $\begin{array}{l}255 / 15.7 \\
37 / 27.4 \\
\end{array}$ & $\begin{array}{l}\mathbf{2 . 0 3} \\
(1.36-3.03)\end{array}$ & $\begin{array}{l}1.38 \\
(0.91-2.10) \\
\end{array}$ & $\begin{array}{l}1.51 \\
(0.98-2.30) \\
\end{array}$ \\
\hline Chronic obstructive pulmonary disease & $\begin{array}{l}\text { No } \\
\text { Yes }\end{array}$ & $\begin{array}{l}1441 / 83.5 \\
28 / 77.8\end{array}$ & $\begin{array}{l}285 / 16.5 \\
8 / 22.2\end{array}$ & $\begin{array}{l}1.45 \\
(0.65-3.20)\end{array}$ & $\begin{array}{l}1.32 \\
(0.59-2.97)\end{array}$ & $\begin{array}{l}1.33 \\
(0.59-2.99)\end{array}$ \\
\hline Diabetes, type 1 & $\begin{array}{l}\text { No } \\
\text { Yes }\end{array}$ & $\begin{array}{l}1455 / 83.3 \\
10 / 90.9\end{array}$ & $\begin{array}{l}291 / 16.7 \\
1 / 9.1\end{array}$ & $\begin{array}{l}0.50 \\
(0.06-3.92)\end{array}$ & $\begin{array}{l}0.54 \\
(0.07-4.40)\end{array}$ & $\begin{array}{l}0.50 \\
(0.06-4.17)\end{array}$ \\
\hline Osteoporosis-related fracture & $\begin{array}{l}\text { No } \\
\text { Yes }\end{array}$ & $\begin{array}{l}1330 / 84.1 \\
135 / 77.6\end{array}$ & $\begin{array}{l}252 / 15.9 \\
39 / 22.4\end{array}$ & $\begin{array}{l}1.53 \\
(1.04-2.23)\end{array}$ & $\begin{array}{l}1.01 \\
(0.68-1.51)\end{array}$ & $\begin{array}{l}0.85 \\
(0.56-1.29)\end{array}$ \\
\hline Hip fracture & $\begin{array}{l}\text { No } \\
\text { Yes }\end{array}$ & $\begin{array}{l}1432 / 83.7 \\
21 / 67.7\end{array}$ & $\begin{array}{l}279 / 16.3 \\
10 / 32.3\end{array}$ & $\begin{array}{l}\mathbf{2 . 4 4} \\
(1.14-5.25)\end{array}$ & $\begin{array}{l}1.59 \\
(0.72-3.54)\end{array}$ & $\begin{array}{l}1.53 \\
(0.68-3.43)\end{array}$ \\
\hline Osteoarthritis of hip and/or knee & $\begin{array}{l}\text { No } \\
\text { Yes }\end{array}$ & $\begin{array}{l}1230 / 85.0 \\
240 / 75.9\end{array}$ & $\begin{array}{l}217 / 15.0 \\
76 / 24.1 \\
\end{array}$ & $\begin{array}{l}\mathbf{1 . 8 0} \\
(1.34-2.41)\end{array}$ & $\begin{array}{l}\mathbf{1 . 5 5} \\
(1.14-2.10)\end{array}$ & $\begin{array}{l}\mathbf{1 . 5 4} \\
(1.14-2.10) \\
\end{array}$ \\
\hline Dementia & $\begin{array}{l}\text { No } \\
\text { Yes }\end{array}$ & $\begin{array}{l}1396 / 83.9 \\
27 / 73.0\end{array}$ & $\begin{array}{l}268 / 16.1 \\
10 / 27.0 \\
\end{array}$ & $\begin{array}{l}1.93 \\
(0.92-4.03) \\
\end{array}$ & $\begin{array}{l}1.21 \\
(0.56-2.59) \\
\end{array}$ & $\begin{array}{l}1.30 \\
(0.60-2.82) \\
\end{array}$ \\
\hline Epilepsy & $\begin{array}{l}\text { No } \\
\text { Yes }\end{array}$ & $\begin{array}{l}1452 / 83.4 \\
13 / 92.9\end{array}$ & $\begin{array}{l}289 / 16.6 \\
1 / 7.1\end{array}$ & $\begin{array}{l}0.39 \\
(0.05-2.97)\end{array}$ & $\begin{array}{l}0.35 \\
(0.04-2.80)\end{array}$ & $\begin{array}{l}0.33 \\
(0.04-2.63)\end{array}$ \\
\hline Parkinson's disease & $\begin{array}{l}\text { No } \\
\text { Yes }\end{array}$ & $\begin{array}{l}1462 / 83.5 \\
5 / 83.3\end{array}$ & $\begin{array}{l}289 / 16.5 \\
1 / 16.7\end{array}$ & $\begin{array}{l}1.01 \\
(0.12-8.69)\end{array}$ & $\begin{array}{l}0.45 \\
(0.05-3.93)\end{array}$ & $\begin{array}{l}0.52 \\
(0.06-4.59)\end{array}$ \\
\hline Anaemia & $\begin{array}{l}\text { No } \\
\text { Yes }\end{array}$ & $\begin{array}{l}1343 / 83.8 \\
77 / 77.0\end{array}$ & $\begin{array}{l}260 / 16.2 \\
23 / 23.0\end{array}$ & $\begin{array}{l}1.54 \\
(0.95-2.50)\end{array}$ & $\begin{array}{l}0.96 \\
(0.58-1.58)\end{array}$ & $\begin{array}{l}1.26 \\
(0.75-2.13)\end{array}$ \\
\hline Depression & $\begin{array}{l}\text { No } \\
\text { Yes }\end{array}$ & $\begin{array}{l}1201 / 84.2 \\
241 / 80.1\end{array}$ & $\begin{array}{l}226 / 15.8 \\
60 / 19.9 \\
\end{array}$ & $\begin{array}{l}1.32 \\
(0.96-1.82)\end{array}$ & $\begin{array}{l}\mathbf{1 . 5 0} \\
(1.08-2.08)\end{array}$ & $\begin{array}{l}1.35 \\
(0.97-1.88)\end{array}$ \\
\hline Psychosis & $\begin{array}{l}\text { No } \\
\text { Yes }\end{array}$ & $\begin{array}{l}1426 / 83.4 \\
33 / 80.5 \\
\end{array}$ & $\begin{array}{l}\text { 283/16.6 } \\
8 / 19.5 \\
\end{array}$ & $\begin{array}{l}1.22 \\
(0.56-2.67) \\
\end{array}$ & $\begin{array}{l}1.40 \\
(0.62-3.14) \\
\end{array}$ & $\begin{array}{l}1.37 \\
(0.61-3.08) \\
\end{array}$ \\
\hline Cognitive impairment & $\begin{array}{l}\text { No } \\
\text { Yes }\end{array}$ & $\begin{array}{l}1330 / 84.4 \\
101 / 72.7 \\
\end{array}$ & $\begin{array}{l}246 / 15.6 \\
38 / 27.3 \\
\end{array}$ & $\begin{array}{l}\mathbf{2 . 0 3} \\
(1.37-3.03)\end{array}$ & $\begin{array}{l}1.32 \\
(0.87-2.01)\end{array}$ & $\begin{array}{l}1.32 \\
(0.87-2.02)\end{array}$ \\
\hline Sleeping disorders & $\begin{array}{l}\text { No } \\
\text { Yes }\end{array}$ & $\begin{array}{l}939 / 85.4 \\
528 / 80.0\end{array}$ & $\begin{array}{l}161 / 14.6 \\
132 / 20.0\end{array}$ & $\begin{array}{l}1.46 \\
(1.13-1.88)\end{array}$ & $\begin{array}{l}\mathbf{1 . 4 0} \\
(1.08-1.82)\end{array}$ & $\begin{array}{l}1.30 \\
(0.99-1.69)\end{array}$ \\
\hline \multicolumn{7}{|l|}{ Medication use } \\
\hline Sedative and hypnotic drugs & $\begin{array}{l}\text { No } \\
\text { Yes }\end{array}$ & $\begin{array}{l}853 / 82.5 \\
183 / 73.5\end{array}$ & $\begin{array}{l}181 / 17.5 \\
66 / 26.5\end{array}$ & $\begin{array}{l}\mathbf{1 . 7 0} \\
(1.23-2.35)\end{array}$ & $\begin{array}{l}1.35 \\
(0.97-1.89)\end{array}$ & $\begin{array}{l}1.28 \\
(0.91-1.79)\end{array}$ \\
\hline Neuroleptic drugs & $\begin{array}{l}\text { No } \\
\text { Yes }\end{array}$ & $\begin{array}{l}1026 / 81.0 \\
10 / 62.5\end{array}$ & $\begin{array}{l}241 / 19.0 \\
6 / 37.5\end{array}$ & $\begin{array}{l}2.55 \\
(0.92-7.10)\end{array}$ & $\begin{array}{l}3.62 \\
(1.27-10.36)\end{array}$ & $\begin{array}{l}3.30 \\
(1.15-9.43)\end{array}$ \\
\hline Anticholinergic drugs & $\begin{array}{l}\text { No } \\
\text { Yes }\end{array}$ & $\begin{array}{l}998 / 80.6 \\
38 / 84.4 \\
\end{array}$ & $\begin{array}{l}240 / 19.4 \\
7 / 15.6\end{array}$ & $\begin{array}{l}0.77 \\
(0.34-1.74)\end{array}$ & $\begin{array}{l}0.65 \\
(0.28-1.49)\end{array}$ & $\begin{array}{l}0.66 \\
(0.29-1.53)\end{array}$ \\
\hline Antihypertensive drugs & $\begin{array}{l}\text { No } \\
\text { Yes }\end{array}$ & $\begin{array}{l}918 / 81.0 \\
118 / 78.7 \\
\end{array}$ & $\begin{array}{l}215 / 19.0 \\
32 / 21.3 \\
\end{array}$ & $\begin{array}{l}1.16 \\
(0.76-1.76) \\
\end{array}$ & $\begin{array}{l}1.08 \\
(0.70-1.65) \\
\end{array}$ & $\begin{array}{l}1.16 \\
(0.75-1.79) \\
\end{array}$ \\
\hline Diuretic drugs & $\begin{array}{l}\text { No } \\
\text { Yes }\end{array}$ & $\begin{array}{l}736 / 82.8 \\
300 / 76.1 \\
\end{array}$ & $\begin{array}{l}153 / 17.2 \\
94 / 23.9 \\
\end{array}$ & $\begin{array}{l}\mathbf{1 . 5 1} \\
(1.13-2.01)\end{array}$ & $\begin{array}{l}1.16 \\
(0.86-1.57)\end{array}$ & $\begin{array}{l}1.19 \\
(0.87-1.61)\end{array}$ \\
\hline Use of fall risk drugs & $\begin{array}{l}\text { No } \\
\text { Yes }\end{array}$ & $\begin{array}{l}983 / 87.1 \\
487 / 76.7\end{array}$ & $\begin{array}{l}145 / 12.9 \\
148 / 23.3\end{array}$ & $\begin{array}{l}\mathbf{2 . 0 6} \\
(1.60-2.66)\end{array}$ & $\begin{array}{l}\mathbf{1 . 5 0} \\
(1.15-1.97)\end{array}$ & $\begin{array}{l}\mathbf{1 . 4 8} \\
(1.13-1.94)\end{array}$ \\
\hline Use of other drugs & $\begin{array}{l}\text { No } \\
\text { Yes }\end{array}$ & $\begin{array}{l}921 / 82.6 \\
549 / 84.7\end{array}$ & $\begin{array}{l}194 / 17.4 \\
99 / 15.3\end{array}$ & $\begin{array}{l}0.86 \\
(0.66-1.12)\end{array}$ & $\begin{array}{l}0.99 \\
(0.75-1.30)\end{array}$ & $\begin{array}{l}0.96 \\
(0.73-1.27)\end{array}$ \\
\hline \multicolumn{7}{|l|}{ Sensory and neuromuscular } \\
\hline Vertigo & $\begin{array}{l}\text { No } \\
\text { Yes }\end{array}$ & $\begin{array}{l}1018 / 85.5 \\
452 / 79.0\end{array}$ & $\begin{array}{l}173 / 14.5 \\
120 / 21.0\end{array}$ & $\begin{array}{l}\mathbf{1 . 5 6} \\
(1.21-2.02)\end{array}$ & $\begin{array}{l}\mathbf{1 . 4 4} \\
(1.10-1.87)\end{array}$ & $\begin{array}{l}\mathbf{1 . 3 6} \\
(1.04-1.78)\end{array}$ \\
\hline Current pain & $\begin{array}{l}\text { No } \\
\text { Yes }\end{array}$ & $\begin{array}{l}663 / 85.3 \\
787 / 81.6\end{array}$ & $\begin{array}{l}114 / 14.7 \\
178 / 18.4\end{array}$ & $\begin{array}{l}1.32 \\
(1.02-1.70)\end{array}$ & $\begin{array}{l}\mathbf{1 . 3 4} \\
(1.03-1.75)\end{array}$ & $\begin{array}{l}1.29 \\
(0.99-1.68)\end{array}$ \\
\hline
\end{tabular}


Table 2 Prevalence of risk factors and their association with falls according to adjusted multiple regression analysis, expressed as odds ratios (OR), $\mathbf{n}=\mathbf{1 7 6 3}$ (Continued)

\begin{tabular}{|c|c|c|c|c|c|c|}
\hline Urine incontinence & $\begin{array}{l}\text { No } \\
\text { Yes }\end{array}$ & $\begin{array}{l}1234 / 84.9 \\
200 / 74.9 \\
\end{array}$ & $\begin{array}{l}219 / 15.1 \\
67 / 25.1 \\
\end{array}$ & $\begin{array}{l}\mathbf{1 . 8 9} \\
(1.38-2.58)\end{array}$ & $\begin{array}{l}1.49 \\
(1.08-2.06)\end{array}$ & $\begin{array}{l}1.31 \\
(0.94-1.82)\end{array}$ \\
\hline Nocturia & $\begin{array}{l}\text { No } \\
\text { Yes }\end{array}$ & $\begin{array}{l}1366 / 84.5 \\
68 / 66.0 \\
\end{array}$ & $\begin{array}{l}251 / 15.5 \\
35 / 34.0 \\
\end{array}$ & $\begin{array}{l}\mathbf{2 . 8 0} \\
(1.82-4.30)\end{array}$ & $\begin{array}{l}\mathbf{1 . 9 5} \\
(1.25-3.05) \\
\end{array}$ & $\begin{array}{l}\mathbf{1 . 7 5} \\
(1.12-2.75) \\
\end{array}$ \\
\hline \multicolumn{7}{|l|}{ Balance and mobility } \\
\hline Tendency to fall & $\begin{array}{l}\text { No } \\
\text { Yes }\end{array}$ & $\begin{array}{l}1335 / 84.1 \\
134 / 77.0\end{array}$ & $\begin{array}{l}253 / 15.9 \\
40 / 23.0\end{array}$ & $\begin{array}{l}\mathbf{1 . 5 8} \\
(1.08-2.30)\end{array}$ & $\begin{array}{l}1.28 \\
(0.87-1.90)\end{array}$ & $\begin{array}{l}1.27 \\
(0.86-1.88)\end{array}$ \\
\hline Pain during movement & $\begin{array}{l}\text { No } \\
\text { Yes }\end{array}$ & $\begin{array}{l}621 / 85.5 \\
849 / 81.9 \\
\end{array}$ & $\begin{array}{l}105 / 14.5 \\
188 / 18.1 \\
\end{array}$ & $\begin{array}{l}1.31 \\
(1.01-1.70)\end{array}$ & $\begin{array}{l}1.39 \\
(1.06-1.82)\end{array}$ & $\begin{array}{l}1.30 \\
(0.99-1.70)\end{array}$ \\
\hline Impaired mobility & $\begin{array}{l}\text { No } \\
\text { Yes }\end{array}$ & $\begin{array}{l}1343 / 85.2 \\
101 / 65.6 \\
\end{array}$ & $\begin{array}{l}233 / 14.8 \\
53 / 34.4\end{array}$ & $\begin{array}{l}3.03 \\
(2.11-4.34) \\
\end{array}$ & $\begin{array}{l}1.65 \\
(1.11-2.45)\end{array}$ & $\begin{array}{l}1.50 \\
(1.00-2.24)\end{array}$ \\
\hline Low walking speed & $\begin{array}{l}\text { No } \\
\text { Yes }\end{array}$ & $\begin{array}{l}851 / 90.4 \\
554 / 76.1\end{array}$ & $\begin{array}{l}90 / 9.6 \\
174 / 23.9\end{array}$ & $\begin{array}{l}\mathbf{2 . 9 7} \\
(2.25-3.91)\end{array}$ & $\begin{array}{l}\mathbf{2 . 0 2} \\
(1.47-2.78)\end{array}$ & $\begin{array}{l}\mathbf{1 . 7 7} \\
(1.28-2.46)\end{array}$ \\
\hline Low physical activity & $\begin{array}{l}\text { No } \\
\text { Yes }\end{array}$ & $\begin{array}{l}1227 / 84.9 \\
223 / 76.1 \\
\end{array}$ & $\begin{array}{l}219 / 15.1 \\
70 / 23.9 \\
\end{array}$ & $\begin{array}{l}\mathbf{1 . 7 6} \\
(1.30-2.39)\end{array}$ & $\begin{array}{l}1.28 \\
(0.93-1.76)\end{array}$ & $\begin{array}{l}1.32 \\
(0.95-1.83)\end{array}$ \\
\hline \multicolumn{7}{|c|}{ Environmental and sociodemographic } \\
\hline Living alone & $\begin{array}{l}\text { No } \\
\text { Yes }\end{array}$ & $\begin{array}{l}931 / 87.2 \\
539 / 77.6 \\
\end{array}$ & $\begin{array}{l}137 / 12.8 \\
156 / 22.4 \\
\end{array}$ & $\begin{array}{l}1.97 \\
(1.53-2.53)\end{array}$ & $\begin{array}{l}\mathbf{1 . 4 6} \\
(1.12-1.91) \\
\end{array}$ & $\begin{array}{l}1.29 \\
(0.98-1.71) \\
\end{array}$ \\
\hline Residential home & $\begin{array}{l}\text { No } \\
\text { Yes }\end{array}$ & $\begin{array}{l}1444 / 83.7 \\
11 / 57.9 \\
\end{array}$ & $\begin{array}{l}281 / 16.3 \\
8 / 42.1 \\
\end{array}$ & $\begin{array}{l}\mathbf{3 . 7 4} \\
(1.49-9.38)\end{array}$ & $\begin{array}{l}1.77 \\
(0.69-4.53)\end{array}$ & $\begin{array}{l}1.81 \\
(0.69-4.72)\end{array}$ \\
\hline Outdoor adaptation & $\begin{array}{l}\text { No } \\
\text { Yes }\end{array}$ & $\begin{array}{l}317 / 84.8 \\
999 / 83.0\end{array}$ & $\begin{array}{l}57 / 15.2 \\
205 / 17.0\end{array}$ & $\begin{array}{l}1.14 \\
(0.83-1.57)\end{array}$ & $\begin{array}{l}1.04 \\
(0.75-1.44)\end{array}$ & $\begin{array}{l}1.04 \\
(0.75-1.45)\end{array}$ \\
\hline Indoor adaptation & $\begin{array}{l}\text { No } \\
\text { Yes }\end{array}$ & $\begin{array}{l}1099 / 85.9 \\
371 / 76.8\end{array}$ & $\begin{array}{l}181 / 14.1 \\
112 / 23.2\end{array}$ & $\begin{array}{l}1.83 \\
(1.41-2.39)\end{array}$ & $\begin{array}{l}\mathbf{1 . 5 0} \\
(1.14-1.97)\end{array}$ & $\begin{array}{l}\mathbf{1 . 4 5} \\
(1.10-1.91)\end{array}$ \\
\hline \multicolumn{7}{|l|}{ Functional ability } \\
\hline Dependence in & No & $1302 / 84.3$ & 243/15.7 & 1.89 & 1.33 & 1.47 \\
\hline iADL & Yes & $125 / 74.0$ & $44 / 26.0$ & $(1.30-2.73)$ & $(0.90-1.96)$ & $(0.99-2.18)$ \\
\hline Dependence in & No & $1131 / 85.4$ & 193/14.6 & 1.86 & 1.49 & 1.35 \\
\hline pADL & Yes & $296 / 75.9$ & $94 / 24.1$ & $(1.41-2.46)$ & $(1.12-1.99)$ & $(1.00-1.81)$ \\
\hline
\end{tabular}

(Bold values indicate statistical significance).

Table 3 Principal component analysis with eligible components and their predicted risk of falling, expressed as odds ratios (OR), $\mathrm{n}=1763$

\begin{tabular}{llll}
\hline & Component and factor loading & & Functional impairment \\
\cline { 2 - 4 } Risk factors & Reduced mobility & Heart dysfunction & \\
\hline Indoor adaptation & .66 & & \\
Osteoarthritis of hip and/or knee & .63 & & \\
Low walking speed & .58 & -.78 & -.71 \\
Impaired mobility & .41 & -.59 & .87 \\
Heart disease & & & .85 \\
Heart failure with symptoms & & & $\mathbf{1 . 3 8}$ \\
Use of fall risk drugs & & $\mathbf{1 . 6 6}$ & $(1.01-1.88)$ \\
Dependence in pADL & & $(1.26-2.20)$ & \\
Nocturia & $\mathbf{2 . 1 2}$ & $(1.54-2.91)$ & \\
\hline OR for falling & & & \\
(95\% Cl) &
\end{tabular}


Table 4 Attrition analysis comparing non-participants to the study population, differences in distributions analysed with the chi-squared test

\begin{tabular}{lllll}
\multicolumn{2}{l}{ Non-participants } & & & \multicolumn{2}{l}{ Study population } \\
\cline { 1 - 1 } $\mathbf{n}=\mathbf{7 7 2}$ & \% & & $\frac{\mathbf{n}=\mathbf{1 7 6 3}}{\mathbf{n}}$ & $\mathbf{p}$ \\
347 & 44.9 & 805 & 45.7 & 0.762 \\
425 & 55.1 & 958 & 54.3 & 0.762 \\
\hline
\end{tabular}

\begin{tabular}{|c|c|c|c|c|c|}
\hline \multicolumn{6}{|l|}{ Sex } \\
\hline Men & 347 & 44.9 & 805 & 45.7 & 0.762 \\
\hline Women & 425 & 55.1 & 958 & 54.3 & 0.762 \\
\hline \multicolumn{6}{|l|}{ Age, decade } \\
\hline 60 & 314 & 40.7 & 979 & 55.5 & $<0.001$ \\
\hline 70 & 147 & 19.0 & 350 & 19.9 & 0.664 \\
\hline 80 & 222 & 28.8 & 379 & 21.5 & $<0.001$ \\
\hline 90 & 89 & 11.5 & 55 & 3.1 & $<0.001$ \\
\hline \multicolumn{6}{|l|}{ Risk factors } \\
\hline \multicolumn{6}{|l|}{ Medical and psychological } \\
\hline Heart disease & 204/766 & 26.6 & $387 / 1759$ & 22.0 & 0.012 \\
\hline Heart failure with symptoms & $97 / 740$ & 13.1 & $91 / 1712$ & 5.3 & $<0.001$ \\
\hline Stroke & $98 / 771$ & 12.7 & $135 / 1758$ & 7.7 & $<0.001$ \\
\hline Chronic obstructive pulmonary disease & $39 / 769$ & 5.1 & $36 / 1762$ & 2.0 & $<0.001$ \\
\hline Diabetes. type 1 & $11 / 766$ & 1.4 & $11 / 1757$ & 0.6 & 0.044 \\
\hline Osteoporosis-related fracture & $119 / 765$ & 15.6 & $174 / 1756$ & 9.9 & $<0.001$ \\
\hline Hip fracture & $27 / 760$ & 3.6 & $31 / 1742$ & 1.8 & 0.007 \\
\hline Osteoarthritis of hip and/or knee & $152 / 772$ & 19.7 & $316 / 1763$ & 17.9 & 0.292 \\
\hline Dementia & $52 / 733$ & 7.1 & $37 / 1701$ & 2.2 & $<0.001$ \\
\hline Epilepsy & $13 / 769$ & 1.7 & $14 / 1755$ & 0.8 & 0.045 \\
\hline Parkinson's disease & $11 / 764$ & 1.4 & $6 / 1757$ & 0.3 & 0.002 \\
\hline Anaemia & $90 / 719$ & 12.5 & 100/1703 & 5.9 & $<0.001$ \\
\hline Depression & $135 / 758$ & 17.8 & $301 / 1728$ & 17.4 & 0.813 \\
\hline Psychosis and other mental illness & $18 / 768$ & 2.3 & $41 / 1750$ & 2.3 & 0.999 \\
\hline Cognitive impairment & $127 / 695$ & 18.3 & 139/1715 & 8.1 & $<0.001$ \\
\hline Sleeping disorders & $317 / 772$ & 41.1 & $660 / 1760$ & 37.5 & 0.090 \\
\hline \multicolumn{6}{|l|}{ Medication use } \\
\hline Sedative and hypnotic drugs & $158 / 630$ & 25.1 & $249 / 1283$ & 19.4 & 0.004 \\
\hline Neuroleptic drugs & $17 / 630$ & 2.7 & $16 / 1283$ & 1.2 & 0.022 \\
\hline Anticholinergic drugs & $34 / 630$ & 5.4 & $45 / 1283$ & 3.5 & 0.051 \\
\hline Antihypertensive drugs & $85 / 630$ & 13.5 & $150 / 1283$ & 11.7 & 0.259 \\
\hline Diuretic drugs & $286 / 630$ & 45.4 & $394 / 1283$ & 30.7 & $<0.001$ \\
\hline Use of fall risk drugs & $393 / 772$ & 50.9 & $635 / 1763$ & 36.0 & $<0.001$ \\
\hline Use of other drugs & $237 / 772$ & 30.7 & $648 / 1763$ & 36.8 & 0.003 \\
\hline \multicolumn{6}{|l|}{ Sensory and neuromuscular } \\
\hline Vertigo & $276 / 772$ & 35.8 & $572 / 1763$ & 32.4 & 0.104 \\
\hline Current pain & $418 / 760$ & 55.0 & $965 / 1742$ & 55.4 & 0.855 \\
\hline Urine incontinence & $149 / 690$ & 21.6 & $267 / 1720$ & 15.5 & $<0.001$ \\
\hline Nocturia & $74 / 690$ & 10.7 & 103/1720 & 6.0 & $<0.001$ \\
\hline \multicolumn{6}{|l|}{ Balance and mobility } \\
\hline Tendency to fall & $121 / 771$ & 15.7 & $174 / 1762$ & 9.9 & $<0.001$ \\
\hline Pain during movement & $441 / 764$ & 57.7 & $1037 / 1763$ & 58.8 & 0.607 \\
\hline
\end{tabular}


Table 4 Attrition analysis comparing non-participants to the study population, differences in distributions analysed with the chi-squared test (Continued)

\begin{tabular}{|c|c|c|c|c|c|}
\hline Impaired mobility & $153 / 700$ & 21.9 & $154 / 1730$ & 8.9 & $<0.001$ \\
\hline Low walking speed & $372 / 617$ & 60.3 & $728 / 1669$ & 43.6 & $<0.001$ \\
\hline Low physical activity & 238/717 & 33.2 & 293/1739 & 16.8 & $<0.001$ \\
\hline \multicolumn{6}{|c|}{ Environmental and sociodemographic } \\
\hline Living alone & $347 / 772$ & 44.9 & $695 / 1763$ & 39.4 & 0.009 \\
\hline Residential home & $28 / 727$ & 3.9 & $19 / 1744$ & 1.1 & $<0.001$ \\
\hline Outdoor adaptation & $496 / 648$ & 76.5 & $1204 / 1578$ & 76.3 & 0.902 \\
\hline Indoor adaptation & $275 / 772$ & 35.6 & $483 / 1763$ & 27.4 & $<0.001$ \\
\hline \multicolumn{6}{|l|}{ Functional ability } \\
\hline Dependence in iADL & $93 / 686$ & 13.6 & $169 / 1714$ & 9.9 & 0.009 \\
\hline Dependence in $\mathrm{pADL}$ & 222/686 & 32.4 & $390 / 1714$ & 22.8 & $<0.001$ \\
\hline
\end{tabular}

in individuals with heart failure approaching the end of life, and there is limited knowledge on the best way to manage these individuals [49]. The elevated risk of falling in the elderly with heart failure may be explained by its pharmacotherapy (e.g. diuretics, ACE inhibitors, betablockers) and their association with falls, although these categories of pharmaceuticals did not individually predict falls in our study. Response to pharmacotherapy for heart failure varies in elderly individuals, who are susceptible to adverse events such as orthostatic hypotension, dehydration, electrolyte disturbance, incontinence and drug-drug interactions [47]. One common side effect of diuretics is hyponatraemia, which is associated with impairment of gait and attention. Stable mild chronic hyponatraemia is generally considered asymptomatic, although Renneboog (2006) observed a high number of falls in comparison to controls in hyponatraemic subjects considered clinically asymptomatic. Furthermore, individuals with moderate chronic hyponatraemia fell dramatically more frequently than patients with normal serum sodium levels [50].

The component functional impairment, including dependence in PADL and nocturia, predicted falls, and has previously been reported to be a risk factor $[2,4,51]$. In the limited studies of fall risk factors in the very elderly, dependence in pADL was found to be one of the most important independent predisposing factors in a population-based study including individuals 85-103 years old [4]. In a recent study, the elevated risk of falling in adults over 85 years appeared to be due to the overall deterioration of health with age. Among those with excellent overall health, the risk of falling in adults over 85 years was no higher than in those $65-84$ years of age [52]. The association between nocturia and falls may be explained by incontinence as a symptom of a general deterioration of health. Night-time visits to the toilet in darkness may also contribute to the risk of falling [53]. There may also be an association between nocturia and the treatment for heart failure, as these groups both showed an elevated risk of falling. As diuretic drugs can cause urge incontinence, orthostatic hypotension and hyponatraemia, their relation to nocturia and night-time falls may be underestimated.

The use of neuroleptics, although the prevalence is low, is found to be a prominent individual risk factor for falls in the present study. Although they have not been as widely studied in this field as other psychotropic and psychoactive drugs, such as SSRIs and sedatives, an association between neuroleptics and falls has been reported previously $[27,39,54]$. Unnecessary or incorrect use of drugs is one of the most easily correctable risk factors for falls in the elderly, and it was shown in a randomised trial that gradual withdrawal of psychotropic drugs reduced the risk of falling by $66 \%$ [55].

\section{Strengths and limitations}

This is a long-term, prospective cohort study of a relatively large sample of a general, elderly population, which can be seen as a strength. A prospective design, allowing the study of outcome following exposure, ranks higher in the hierarchy of evidence, than retrospective or cross-sectional studies [18]. Studying the effect of risk factors on falls over an extended period may provide valuable information for future fall-prevention programmes. As a long-term, persistent reduction of falls are desirable, an intervention on risk factors identified in long-term prospective studies, may results in sustainable reduction of falls in the elderly. Although this is a prospective study of risk factors for falls, the direct causality of falls cannot be identified using this epidemiological approach. The risk factors predicting falls, described in this study, are rather markers of an increased probability of a future fall.

Unfortunately, selection bias cannot be ruled out in this study, despite the fact that home visits were offered to those who were unable to come to the research 
centre. Older and more infirm subjects did not participate in the study to the same extent as younger and healthier individuals. The attrition analysis confirmed that there were significantly relatively more older, and assumingly frailer, subjects in the group of nonparticipants than in the study population. The majority of the fall risk factors considered in this study had a significantly higher relative prevalence in the nonparticipants than in those included in the study. A selection bias, leading to underrepresentation of older and frailer individuals, and diagnoses such as stroke and dementia, may have reduced the predicted fall risk in this study.

The reported incidence of falls during the past six months for the older cohorts at the 3-year follow-up assessment (19.1\%), and at the 6-year follow-up assessment (13.3\%) are low compared to those reported in previous studies $[1,2,7,11]$. Apart from selection bias and attrition after six years, the low incidence observed here may be due to a general better health in the population studied, than previously assumed. Furthermore, the gender distribution was very equal in the study population. Previous studies of risk factors associated with falls have shown a tendency towards the recruiting of more women than men, which may introduce bias, as women are more prone to fall than men [19].

The long-term design of this study leads to a number of methodological limitations in recording falls, which will affect the reliability and validity of the dependent variable. The Prevention of Falls Network Europe (ProFaNE) collaborators' recommendation of weekly, monthly or bi-monthly recording of falls in prospective studies was not possible in this epidemiological study [31,32]. Falls six months prior the follow-up assessments were recorded, which means there was a relatively long period during which falls or other adverse events could have taken place. It was not possible to specify the occurrence, severity or frequency of falls with the dichotomized approach used here. Falls were recorded by purpose-trained physicians in face-to-face interviews, using a structured questionnaire. The recommended ProFaNE definition of a fall $[31,32]$ was not used. Although there is no universally accepted method of reporting falls, and the elderly may intuitively give correct information, this is a limitation of the study. As falls are common in the elderly population, our approach may have led to underreporting and misclassification of these events. Despite this, the likelihood of this possible bias producing false positive conclusions would have been limited. As the incidence of falls is very likely to be underreported, it rather reduces the significance and strength of the results throughout the study.

\section{Conclusions}

Three main components predicting falls were identified in a general elderly population after three and six years: reduced mobility, heart dysfunction, and functional impairment including nocturia. Furthermore, the use of neuroleptic drugs, although low in prevalence, was a prominent individual risk factor. Heart failure with symptoms was a significant risk factor for falls, and may be of clinical importance as the prevalence in the elderly is increasing worldwide. There is need for further research on the relation between heart failure and falls in the elderly, as the treatment of the condition is poorly documented in this demographic. The findings of this study may be valuable for future trials aimed at sustainable, long-term reduction of falls in the elderly.

\section{Competing interests}

The authors declare that they have no competing interest.

\section{Authors' contributions}

MS drafted the manuscript and was the main author. MS, HE, EN and SE took part in the methodological decisions, statistical analyses and interpretation of data, commented on the draft, and all authors read and approved the final version. SE was the main planner of the study.

\section{Acknowledgements}

The project Good Ageing in Skåne, part of the Swedish National Study on Aging and Care, was supported by the Swedish Ministry of Health and Social Affairs, the Regional authority Region Skåne, the Medical Faculty at Lund

University, the Vårdal Institute and the insurance company Länsförsäkringar.

Received: 2 October 2012 Accepted: 31 July 2013

Published: 7 August 2013

\section{References}

1. Gillespie LD, Robertson MC, Gillespie WJ, Sherrington C, Gates S, Clemson $\mathrm{LM}$, Lamb SE: Interventions for preventing falls in older people living in the community. Cochrane Database Syst Rev 2012, 9:CD007146.

2. Anonymous: Guideline for the prevention of falls in older persons. American Geriatrics Society, British Geriatrics Society, and American Academy of Orthopaedic Surgeons Panel on Falls Prevention. J Am Geriatr Soc 2001, 49(5):664-672.

3. Ganz DA, Bao Y, Shekelle PG, Rubenstein LZ: Will my patient fall? JAMA 2007, 297(1):77-86.

4. von-Heideken WP, Gustafson Y, Kallin K, Jensen J, Lundin-Olsson L: Falls in very old people: the population-based Umea 85+ study in Sweden. Arch Gerontol Geriatr 2009, 49(3):390-396.

5. Gama ZA, Gomez-Conesa A: Risk factors for falls in the elderly: systematic review. Rev Saude Publica 2008, 42(5):946-956.

6. Kalache A, Keller I: The greying world: a challenge for the twenty-first century. Sci Prog 2000, 83(Pt 1):33-54.

7. Rubenstein LZ: Falls in older people: epidemiology, risk factors and strategies for prevention. Age Ageing 2006, 35(Suppl 2):ii37-ii41.

8. Kannus P, Sievanen H, Palvanen M, Jarvinen T, Parkkari J: Prevention of falls and consequent injuries in elderly people. Lancet 2005, 366(9500):1885-1893.

9. Jørstad EC, Hauer K, Becker C, Lamb SE: Measuring the psychological outcomes of falling: a systematic review. JAGS 2005, 53:501-510.

10. World Health Organization: WHO global report on falls prevention in older age. Geneva: World Health Organization; 2007.

11. Tinetti ME, Kumar C: The patient who falls: "It's always a trade-off" JAMA 2010, 303(3):258-266.

12. Blank WA, Freiberger $E$, Siegrist $M$, Landendoerfer $P$, Linde $K$, Schuster $T$, Pfeifer K, Schneider A, Halle M: An interdisciplinary intervention to prevent falls in community-dwelling elderly persons: protocol of a cluster-randomized trial [PreFalls]. BMC Geriatr 2011, 11:7-2318-11-7.

13. Chang JT, Morton SC, Rubenstein LZ, Mojica WA, Maglione M, Suttorp MJ, Roth EA, Shekelle PG: Interventions for the prevention of falls in older 
adults: systematic review and meta-analysis of randomised clinical trials. BMJ 2004, 328(7441):680

14. Gates S, Fisher JD, Cooke MW, Carter YH, Lamb SE: Multifactorial assessment and targeted intervention for preventing falls and injuries among older people in community and emergency care settings: systematic review and meta-analysis. BMJ 2008, 336(7636):130-133.

15. Lord SR, Tiedemann A, Chapman K, Munro B, Murray SM, Gerontology M, Ther GR, Sherrington C: The effect of an individualized fall prevention program on fall risk and falls in older people: a randomized, controlled trial. J Am Geriatr Soc 2005, 53(8):1296-1304.

16. Oliver D, Daly F, Martin FC, McMurdo ME: Risk factors and risk assessment tools for falls in hospital in-patients: a systematic review. Age Ageing 2004, 33(2):122-130.

17. Vieira ER, Freund-Heritage $R$, da-Costa BR: Risk factors for geriatric patient falls in rehabilitation hospital settings: a systematic review. Clin Rehabil 2011, 25(9):788-799.

18. Altman DG: Systematic reviews of evaluations of prognostic variables. BMJ 2001, 323(7306):224-228.

19. Deandrea S, Lucenteforte E, Bravi F, Foschi R, La-Vecchia C, Negri E: Risk factors for falls in community-dwelling older people: a systematic review and meta-analysis. Epidemiology 2010, 21(5):658-668.

20. Czerwinski E, Bialoszewski D, Borowy P, Kumorek A, Bialoszewski A: Epidemiology, clinical significance, costs and fall prevention in elderly people. Ortop Traumatol Rehabil 2008, 10(5):419-428.

21. Saari P, Heikkinen E, Sakari-Rantala R, Rantanen T: Fall-related injuries among initially 75- and 80-year old people during a 10-year follow-up. Arch Gerontol Geriatr 2007, 45(2):207-215.

22. Pluijm SM, Smit JH, Tromp EA, Stel VS, Deeg DJ, Bouter LM, Lips P: A risk profile for identifying community-dwelling elderly with a high risk of recurrent falling: results of a 3-year prospective study. Osteoporos Int 2006, 17(3):417-425.

23. Anstey KJ, von-Sanden C, Luszcz MA: An 8-year prospective study of the relationship between cognitive performance and falling in very old adults. J Am Geriatr Soc 2006, 54(8):1169-1176.

24. Lagergren M, Fratiglioni L, Hallberg IR, Berglund J, Elmstahl S, Hagberg B, Holst G, Rennemark M, Sjolund BM, Thorslund M, Wiberg I, Winblad B, Wimo A: A longitudinal study integrating population, care and social services data. The Swedish National study on Aging and Care (SNAC). Aging Clin Exp Res 2004, 16(2):158-168.

25. Cumming RG: Epidemiology of medication-related falls and fractures in the elderly. Drugs Aging 1998, 12(1):43-53.

26. Monane M, Avorn J: Medications and falls. Causation, correlation, and prevention. Clin Geriatr Med 1996, 12(4):847-858.

27. Huang AR, Mallet $L$, Rochefort CM, Eguale T, Buckeridge DL, Tamblyn R: Medication-related falls in the elderly: causative factors and preventive strategies. Drugs Aging 2012, 29(5):359-376

28. Echt MA, Samelson EJ, Hannan MT, Dufour AB, Berry SD: Psychotropic drug initiation or increased dosage and the acute risk of falls: a prospective cohort study of nursing home residents. BMC Geriatr 2013, 13:19-2318-13-19.

29. Lord SR, Sherrington C, Menz HB: Falls in older people: risk factors and strategies for prevention. Cambridge University Press; 2007.

30. Stenhagen $M$, Nordell E, Elmståhl S: Falls in elderly people: a multifactorial analysis of risk markers using data from the Swedish general population study 'Good Ageing in Skåne'. Aging Clin Exp Res 2013, 25(1):59-67.

31. Lamb SE, Jorstad-Stein EC, Hauer K, Becker C, Prevention of Falls Network Europe and Outcomes Consensus Group: Development of a common outcome data set for fall injury prevention trials: the Prevention of Falls Network Europe consensus. J Am Geriatr Soc 2005, 53(9):1618-1622.

32. Hauer K, Lamb SE, Jorstad EC, Todd C, Becker C, PROFANE-Group: Systematic review of definitions and methods of measuring falls in randomised controlled fall prevention trials. Age Ageing 2006, 35(1):5-10.

33. American Heart Association: Classes of heart failure; 2013. http://www.heart org/HEARTORG/Conditions/HeartFailure/AboutHeartFailure/Classes-of-HeartFailure_UCM_306328_Article.jsp Accessed January 2013.

34. List of analysis, clinical chemistry Malmö/Trelleborg; 2013. http://www. analysportalen-labmedicin.skane.se/viewAnalys.asp? $\mathrm{Nr}=2224$ Accessed January 2013

35. Folstein MF, Folstein SE, McHugh PR: Mini-mental state. A practical method for grading the cognitive state of patients for the clinician. J Psychiatr Res 1975, 12(3):189-198.
36. WHO Collaborating Centre for Drug Statistics Methodology: Structures and principles; 2013. http://www.whocc.no/atc/structure_and_principles/ Accessed January 2013

37. Berdot S, Bertrand M, Dartigues JF, Fourrier A, Tavernier B, Ritchie K, Alperovitch A: Inappropriate medication use and risk of falls--a prospective study in a large community-dwelling elderly cohort. BMC Geriatr 2009, 9:30-2318-9-30.

38. Woolcott JC, Richardson KJ, Wiens MO, Patel B, Marin J, Khan KM, Marra CA: Meta-analysis of the impact of 9 medication classes on falls in elderly persons. Arch Intern Med 2009, 169(21):1952-1960

39. Bloch F, Thibaud M, Dugue B, Breque C, Rigaud AS, Kemoun G: Psychotropic drugs and falls in the elderly people: updated literature review and meta-analysis. J Aging Health 2011, 23(2):329-346.

40. Mattiasson-Nilo I, Sonn U, Johannesson K, Gosman-Hedstrom G, Persson GB, Grimby G: Domestic activities and walking in the elderly: evaluation from a 30-hour heart rate recording. Aging (Milano) 1990, 2(2):191-198.

41. Asberg $\mathrm{KH}$, Sonn $\mathrm{U}$ : The cumulative structure of personal and instrumental ADL. A study of elderly people in a health service district. Scand J Rehabil Med 1989, 21(4):171-177.

42. Sonn $\mathrm{U}$, Asberg $\mathrm{KH}$ : Assessment of activities of daily living in the elderly. A study of a population of 76-year-olds in Gothenburg, Sweden. Scand J Rehabil Med 1991, 23(4):193-202.

43. Quach L, Galica AM, Jones RN, Procter-Gray E, Manor B, Hannan MT, Lipsitz $L A$ : The nonlinear relationship between gait speed and falls: the maintenance of balance, independent living, intellect, and zest in the elderly of Boston study. J Am Geriatr Soc 2011, 59(6):1069-1073.

44. Muraki S, Akune T, Oka H, Ishimoto Y, Nagata K, Yoshida M, Tokimura F, Nakamura K, Kawaguchi H, Yoshimura N: Physical performance, bone and joint diseases, and incidence of falls in Japanese men and women: a longitudinal cohort study. Osteoporos Int 2013, 24(2):459-466.

45. Muraki S, Akune T, Oka H, En-Yo Y, Yoshida M, Nakamura K, Kawaguchi H, Yoshimura N: Prevalence of falls and the association with knee osteoarthritis and lumbar spondylosis as well as knee and lower back pain in Japanese men and women. Arthritis Care Res (Hoboken) 2011, 63(10):1425-1431.

46. Panel on Prevention of Falls in Older Persons, American Geriatrics Society and British Geriatrics Society: Summary of the Updated American Geriatrics Society/British Geriatrics Society clinical practice guideline for prevention of falls in older persons. J Am Geriatr Soc 2011, 59(1):148-157.

47. Cheng JW, Nayar M: A review of heart failure management in the elderly population. Am J Geriatr Pharmacother 2009, 7(5):233-249.

48. Ahmed A: American College of Cardiology/American Heart Association Chronic Heart Failure Evaluation and Management guidelines: relevance to the geriatric practice. J Am Geriatr Soc 2003, 51(1):123-126.

49. Tevendale E, Baxter J: Heart failure comorbidities at the end of life. Curr Opin Support Palliat Care 2011, 5(4):322-326.

50. Renneboog B, Musch W, Vandemergel X, Manto MU, Decaux G: Mild chronic hyponatremia is associated with falls, unsteadiness, and attention deficits. Am J Med 2006, 119(1):71.e1-71.e8.

51. Akyol AD: Falls in the elderly: what can be done? Int Nurs Rev 2007, 54(2):191-196

52. Grundstrom AC, Guse CE, Layde PM: Risk factors for falls and fall-related injuries in adults 85 years of age and older. Arch Gerontol Geriatr 2012, 54(3):421-428.

53. Voermans NC, Snijders AH, Schoon Y, Bloem BR: Why old people fall (and how to stop them). Pract Neurol 2007, 7(3):158-171.

54. Kallin K, Jensen J, Olsson LL, Nyberg L, Gustafson Y: Why the elderly fall in residential care facilities, and suggested remedies. J Fam Pract 2004, 53(1):41-52

55. Campbell AJ, Robertson MC, Gardner MM, Norton RN, Buchner DM: Psychotropic medication withdrawal and a home-based exercise program to prevent falls: a randomized, controlled trial. J Am Geriatr SoC 1999, 47(7):850-853.

doi:10.1186/1471-2318-13-81

Cite this article as: Stenhagen et al:: Falls in the general elderly population: a 3- and 6- year prospective study of risk factors using data from the longitudinal population study 'Good ageing in Skane'. BMC Geriatrics 2013 13:81. 